\title{
2 \\ Government budgeting and the quest for value-for-money outcomes in Australia
}

\author{
John Wanna
}

Government executive budgeting in Australia is fundamentally premised on parliamentary scrutiny and endorsement. This provides not only the formal legality for all public finance, but also a degree of transparency, information-sharing and the possibility of investigation. Governments legally require authorisation from the legislature for imposing taxation or raising other revenue and for spending from its consolidated revenue fund. Four key empowering clauses in the Australian Constitution apply to government financing: Section 51 (currency, taxes, borrowing, spending and property acquisition), Section 56 (the financial initiative of the executive), Section 83 (monies only legally drawn from the Treasury if appropriated lawfully) and Section 90 (the Commonwealth's exclusive power to impose customs and duties). Other sections specify how money bills must be handled, but these four important sections constitute the Commonwealth's principal financial powers. While the subnational jurisdictions follow similar budgetary procedures, they have no such constitutional stipulations.

Each year in May, annual budget statements including any new policy proposals announced in separate documentation are presented to parliament for approval. These documents remain the executive's intended 
budget and are not initiated or 'owned' by the legislature, but the bicameral parliament is formally required to appropriate all expenditures and authorise any changes to revenue to ensure their legality. Parliament is not required to 'pass' the budget documents (merely noting these various documents, which are formally 'tabled' and therefore become public documents), but instead authorises a small number of very skeletal appropriation bills giving legal effect to expenditures, and then deliberates any other subsequent revenue and expenditure measures separately. Other than receiving these appropriation bills initiated in the lower house and legally passing them through both houses (or rejecting aspects of them), the Constitution is silent on any other roles for parliament (or the executive) in presenting budgets. However, the Constitution does insist that the bill covering the 'ordinary annual services of the government' shall deal only with those items (effectively, the base budget for the Commonwealth), and this has meant that, since 1965, a separate appropriation bill (Bill No. 2) has been reserved for other items of new spending, capital injections or transfers to the states. Since the late 1990s, the parliament has received a third appropriation bill containing the budgets of the legislature itself and a few independent officers of the parliament (e.g. the auditor-general and the parliamentary budget officer). Additional appropriations for entitlements (special appropriations) and for additional estimates can be passed at other times or later in the budget year.

It is the executive's primary responsibility to steer its budget through the legislature (or secure as much of it as it can through the Senate, where the government of the day often does not command a majority in the upper house). Approval is not automatic or necessarily expected. There have been many instances where governments have not received approval for key measures included in their proposed budget and a few occasions when the budget has met with fierce resistance and a sequence of measures have been rebuffed (e.g. in 1975, 1993 and 2014) (see Young 1996). In recent years, governments have provided more transparency with their budget documentation, trying to keep parliament better informed, but the material has also become highly technical, especially with the transition to accrual reporting of budgets and multiple budgetary balances (fiscal, underlying, headline). However, some useful information once produced in previous decades has been discontinued - for example, historical timeseries of functional outlays, senior executive remunerations, maintenance and some smaller capital works. Over the past 30 years, budgets have become less compliance based and more managerial in orientation as 
Australia moved from line-item funding with firm central input controls to one-line budgeting on a results basis (using an outputs and outcomes framework for the Commonwealth's own-use spending, approximating 20 per cent of total expenses). There were many accompanying budgetary reforms associated with this transition to a results-based budgetary process (see Wanna et al. 2000, 2010; Blöndal 2008; Di Francesco and Alford 2016); some have been retained and built on (e.g. the link to corporate plans, consistent 'line of sight' reporting, resource agreements, one-line budgets for operating costs, budgetary offsets and efficiency dividends), but many others were tried and soon discarded (e.g. multiagency portfolio budgets, the annual capital charging of departments, individual agency bank accounts, the devolution of forward and budget estimates calculations to line agencies, purchasing and property management and cashed provisions for depreciation). Reporting on progress with budgetary implementation and an annual reconciliation statement of the final budget outcome is now more seamless and interconnected under the Charter of Budget Honesty Act, which mandates reporting requirements and consistency over the entire budgetary cycle. This Act provides a consistent set of statutory reporting requirements for budget estimates against eventual actuals.

It should also be remembered that, in population terms, Australia is a relatively small federation, a continental country with an imperious national government (but often limited in its constitutional powers) and eight relatively active subnational governments (six states and two territories). This implies, first, that Australia has not one unitary budgetary system, but nine differentiated processes across the jurisdictions, each with their own priorities, characteristics and often timing; and second, with a high degree of fiscal centralisation, the federal government is highly active in providing intergovernmental financial transfers under various 'agreed' funding criteria (often termed 'executive federalism' because most of this activity involves interexecutive bargaining, not in the various legislatures). These transfers can involve direct untied grants, tied grants for specific purposes stipulated by the Commonwealth, matching project grants for which both levels of jurisdiction agree to joint funding and performancerelated national partnership payments through the Council of Australian Governments (COAG) (previously, federal governments have provided some special grants to activities within the states' responsibilities but these have now been declared ultra vires by the High Court). 
From a budgetary perspective, there are three main problems with this fragmented federalist system of budgeting: 1) the economies and demographics of the various states can move at different speeds, making national management difficult for the federal government and its budget settings; 2) states and territories can actively work against the fiscal strategies of the federal government with different spending and funding priorities or expansionary/contractionary tensions; and 3) the states' budgetary positions have become increasingly dependent on the largesse of the federal government, which is guided by redistributive "horizontal equalisation' principles. This redistributive aspect establishes a perverse logic whereby a state wishing to increase its tax take within its own jurisdiction can subsequently be penalised by receiving lower federal funding from Canberra (a particularly vexing problem that besets the distribution of the nationally collected 10 per cent goods and service tax and pits the larger/richer jurisdictions against the smaller/weaker ones).

This chapter briefly introduces budgeting and budgetary management in Australia, focusing on the federal level. It then explores the various stages of the budget cycle, beginning with the pre-authorisation period before the budget is presented to parliament, the authorisation stage conducted in public through the legislature, followed by the post-authorisation stage where various formal evaluations occur, asking what degree and types of value-for-money investigations are made (routinely or exceptionally). It concludes by examining the strengths and weaknesses of the Australian budgetary management system according to the level of integrated accountability, the coherence of the monitoring and scrutiny processes and performance improvement.

\section{Australia's budgetary processes}

Budgetary processes in Australia are a combination of top-down orchestration and bottom-up estimations of base budgets. Top-down factors may involve some strategic framing, the issuance of fiscal guidelines, decisions about key government priorities (usually expressed in writing and communicated through such devices as the prime minister's charter letters to ministers and senior agency heads), politically imposed aggregate expenditure limits or savings measures and even privatisations or asset sales. It also includes a medium-term fiscal framework (MTFF) covering the budget year plus three further out-years, tabled in parliament, which 
forms the 'hard' basis of future budgets, as well as a mid-year economic and fiscal update that revises estimates and can be used to rein in spending. Bottom-up processes tend to take place throughout the budgetary year, involving the monitoring of all expenses within tolerance parameters, calculation and recalibration of actuals, revision of estimates and re-agreeing estimates between central and line agencies. Colloquially, this has led to the adoption of what is often termed a 'measures and pressures' approach, which also serves as a convenient methodology for budget preparation. 'Measures' include any new policy proposals, adjustments to existing policy of funding packages, expenditure tightening options, efficiency measures or any budget-balancing instruments such as tax increases, reductions in concessions or changes to eligibility criteria. 'Pressures' consist of a duality of factors: the economic growth forecasts including fiscal projections impacting on the budgetary position and inbuilt cost pressures from existing programs or spending allocations (e.g. inflation, enterprise bargaining outcomes, particular cost pressures on certain inputs and changing demographic pressures such as the age pension/aged care implications imposed by an ageing population).

The base budget of most agencies and programs is largely administratively agreed between central agency and line officials, unless cabinets insist on extraordinary cutbacks (as in 1996 and again in 2014). These administrative assessments are usually made on the assumption of maintaining the quality and level of existing services, not necessarily value-for-money criteria. This point was made in an earlier Organisation for Economic Co-operation and Development (OECD) study of Australia (Kraan et al. 2012), which explored aspects of budget reforms, spending reviews and recommendations for future improvement. ${ }^{1} \mathrm{New}$ policy proposals and changes to existing policy settings go to the powerful Expenditure Review Committee (ERC) of cabinet (senior ministers who act as fiscal guardians), which, by dividing bids from ministers/agencies into minor and major proposals, evaluates and ranks the merits of the various bids (producing 'one principal moment' of budgetary deliberation with a running scorecard totalling probable, possible and unlikely proposals). Once all spending decisions have been made (usually by March-April) then there is a final 'hunting season', which allows the central budget

1 Although this OECD study (Kraan et al. 2012) was referred to as a 'value-for-money in government' study and was part of a cross-national comparative survey, for the most part, the analysis presented was of budgetary and managerial reform initiatives. Only sections dealing with spending reviews and market testing touched on value-for-money considerations. 
agency (the Department of Finance) to look for additional savings and present these options to the ERC for approval (see Hawke and Wanna 2010), followed by a review of revenue measures to establish whether any reductions or increases in revenue are warranted by the Revenue Review Committee (RRC). The final two to three weeks before the budget is tabled are spent refining the sales pitch for the budget, honing key messages, promoting the highlights, dropping selective leaks to manage expectations and briefing government ministers and backbenchers.

The main budgetary orchestrating actors include three central agenciesTreasury, the Department of Finance and the Department of the Prime Minister and Cabinet (PM\&C) — that play complementary roles but also serve two powerful budgetary cabinet committees (the ERC and the $\mathrm{RRC}$ ) and have input into various ad hoc strategic budget reviews by the most senior ministers. ${ }^{2}$ These political and bureaucratic institutions have generally worked collaboratively and with a high degree of coordination (which is not to say they do not have occasional differences of opinion over selected aspects of the budget). The ERC has a huge workload making decisions that require the authority of the most senior members of the government, meeting over six months with an intensive period in February and March each year. The RRC has a far lighter workload and may meet perhaps only once a year, usually towards the end of the process, to decide on any tweaking of tax rates. In servicing both these cabinet committees, the Departments of Treasury and Finance provide the updated data and analytical capacities, while $P M \& C$ provides the prime minister with individual advice, monitors the budgetary assemblage and conveys the prime minister's preferences regularly to the other players. Treasury's main focus as the leading economic adviser to government is macroeconomic policy, the intersection of monetary and fiscal policy, international financial developments, microeconomic reform, taxation reform and intergovernmental transfers. The Department of Finance is the main housekeeping budgetary agency responsible for expenditure management, estimates, financial management, asset management and

2 Since the late 1990s, various strategic forums of the most senior ministers have been held, usually in November each year. These have included the Senior Ministers' Retreat, then the Senior Ministers' Review, then the Strategic Budget Committee, followed by the Strategic Policy and Budget Committee. These usually off-site meetings of the prime minister, deputy prime minister, treasurer and minister for finance predetermine the key strategic parameters for the upcoming budget deliberations - and have often been followed by the prime minister issuing his/her charter letters to the ministry (see Blöndal 2008; Hawke and Wanna 2010). 
procurement, budgetary rules and processes. $\mathrm{PM} \& \mathrm{C}$ has a smaller advisory capacity on fiscal and economic policy, but has the prime minister's ear and coordinates the formulation process.

Other sources of expertise and budgetary input include the Commonwealth's line departments and agencies, the central agencies located in subnational jurisdictions, plus various specialist agencies that can influence decision-making, including (within government) the Productivity Commission (an independent long-term economic and social policy adviser; see Chapter 3 by Mike Woods in this volume), the Australian Bureau of Statistics (key statistical indicators), the Australian Taxation Office (taxation advice), the Australian National Audit Office (ANAO) (audit findings) and (outside government) key interests groups from business, unions, farmers, consumers, welfare lobbyists, think tanks and economic/fiscal consulting firms and accounting firms, the media and a diverse group of academics and professionals (e.g. doctors and psychologists on health issues or engineers on infrastructure needs).

Although Australia's budgetary timetable follows the same repetitive patterns, the central budgetary agencies tend to focus their attention on the formulation stages, whereas line agencies tend to make budgetary submissions while focusing on the implementation and review stages of the process (see Appendix 2.1). Operating across a budgetary three-year cycle of formulation (nominally year -1 ), implementation (year 0 ) and evaluation (year +1 ), Finance and Treasury's timetable usually starts around November in year -1 and goes through to the annual reports and final budget outcome midway through year +1 , but their main analytical focus is concentrated on February to June in year $-1 .{ }^{3}$ Line agencies use a different timeline, which typically starts around two years prior to the budget year (years -2 and -1 ), with ongoing research, program reviews, evaluation, feedback from stakeholders and feedback from administration-all of which goes to inform the eventual annual budget submission from the minister, which is submitted in December. The agency then goes into more detail in preparation for the implementation year (year 0 , in which the agency expends that year's annual budget allocation) and then into year +1 for further implementation and evaluation.

3 Australia's budgetary year follows the official financial year that starts from 1 July and runs until 30 June. Hence, both the formulation year $(-1)$ and the implementation year $(0)$ would run from July of one year to the end of June the next. The evaluation year $(+1)$ can run longer than 12 months, depending on the length and magnitude of official reviews by both the ANAO and/or parliamentary committees. 


\section{Assessing value for money in the pre-authorisation stages}

The degree to which value-for-money assessments are made in the preauthorisation stages (i.e. when the executive is drafting its preferred budget in secret) is usually fragmented and focuses on specific facets of the process as information is being sought and decisions are being made. There is no overarching or comprehensive value-for-money assessment of the entire budget in this stage, and most of the tough decisions (reallocations, cuts, offsets, program lapsing) are usually not made public but are promulgated and prosecuted in secret. Governments may conduct expenditure reviews, strategic reviews or capability reviews (and usually only in small numbers), but these are not necessarily linked or integrated with budget setting, and often focus on policy-administrative alignments. So the degree to which value-for-money analyses are influential in this stage is something of a black box, and even the actors most closely involved in budget framing will not have complete knowledge of all the investigations and modifications. The economic, fiscal and political contexts tend to dictate the degree of 'toughness' or 'easiness' displayed by the central budgetary institutions.

The first phase in budgetary analysis involves the ability to accurately estimate revenue and expenses, which remain confidential throughout this period but which will subsequently be published and subject to public accountability. Internal bureaucratic analysis of the forward estimates (the MTFF) is not simply an exercise in arithmetic, because the various players are not neutral and disinterested. All budget actors are contestants, and budgetary processes have to allow for the inclusion of contestable spaces in which to weigh contending and countervailing arguments. This is often referred to in Western democracies as the 'challenge function' or the intentional tension that is institutionalised between guardian and spending actors who perform different roles but must work within and cultivate long-term relations (see Heclo and Wildavsky 1974; Kelly and Wanna 2001). The 'challenge function' may be exploited to contest the accuracy of program or administrative costings, question parameter estimates or take-up rates or challenge the behavioural assumptions of the community - all of which, even with only minor changes, can vary estimates greatly. 
In making expenditure estimates, central budget agencies have distinct advantages here because they not only have an authoritative and positional advantage in setting and agreeing estimates, but also can monitor spending progress in the budgetary implementation out-year and can rein in spending to come within budget projections. So, for example, the Department of Finance has final authority over the forward estimates of agencies and of all costings to cabinet. Not surprisingly, an ANAO performance report into the accuracy of budgetary estimates found that Treasury/Finance were accurate to within 0.65 per cent over a five-year period in the late 1990s (ANAO 1999), which was three times more accurate than their UK and New Zealand counterparts and seven times more reliable than Canada. Finance routinely assesses the accuracy of its own expenditure estimates, using this as a marker of the quality of its work, and selectively publishes results in its annual reports. Estimating revenue is much harder and Treasury traditionally erred on the prudential side, using conservative estimates (possibly as a way to constrain the appetite of ministers for more spending or to eventually produce a better-than-expected budget balance). However, in recent years, in the aftermath of the Global Financial Crisis (GFC), the Treasury has routinely produced overly optimistic revenue projections, which have proved to be exaggerated (Gregory 2017). Given that successive cabinets (under the leadership of Kevin Rudd, Julia Gillard, Tony Abbott and Malcolm Turnbull) have generally fashioned their spending plans in budget formulation against these optimistic revenue projections, such misjudgments probably contributed to larger deficits than otherwise might have been expected. Some governments-most notably, the Gillard Government-have even approved major long-term policy commitments (running out to 10 years) that were largely unfunded given the sluggishness of current revenue receipts (e.g. by announcing indicative funding targets for national disability provision and major augmentations to spending on schools, both constituting nominal public commitments but without funding plans, and certainly not legislated at the time of announcement). Moreover, many infrastructure projects are announced without a detailed business plan being made public, such as with the rollout of the National Broadband Network.

Australia's confidential bidding process for new and/or revised policies provides an internal forum for potentially evaluating the likely returns on public investments (Wanna et al. 2000; Blöndal 2008). All new policies requiring additional funding are submitted to the central budget agencies for evaluation and follow preset timelines and routines. Consolidated 
bidding procedures allow governments to evaluate spending proposals comparatively, investigate and compare the likely costs (and benefits) of proposals, consider alternative policy designs in making value-for-money assessments and rank preferred spending priorities. Through cabinet budgetary committees, senior government ministers can weigh policies on national security, infrastructure, social programs, communications, education or the environment in a closed, secretive forum (Dowding and Martin 2017). Spending agencies may try to pad bids or 'game the system' in other ways, but the principal job of Treasury and Finance is to call their bluff, advise on the merits of the proposals versus other courses of action, challenge the costings and, if approving, recommend levels of funding (full, partial, pilot or fully offset). Central agencies may also propose alternative policy options, modified implementation or delivery methods or suggest different rollout speeds. Central officials usually analyse and approve minor bids in consultation with agencies, while the ERC handles and ranks the larger bids. The 'challenge function' is tempered in democratic societies as there is an expectation that democratically elected governments will want to spend funds on policies attractive to voters to enhance their prospects of re-election (see Posner and Blöndal 2012).

At the federal level, Australia has adopted a particular accounting technique that essentially produces a bifurcation of the expenses allocated to agencies. It separates 'departmental expenses' (their own operating or running costs) from 'administered items' (funds they administratively distribute to others, nominally allocated to capped programs). This legal separation effectively contains departmental expenses (placing caps on expenditure that can be used only for operational purposes) and reserves earmarked funds for spending programs or grants the department merely administers. ${ }^{4}$ Departments then have an incentive to manage within their flexible 'one-line' budget (departmental expenses) as they ought to manage within budget limits and can, in theory, carry forward into next year's budget any unspent funds in their departmental allocation. At the end of the financial year, any unspent funds in the administered items category are returned to the government for reallocation. This separation

4 State and territory governments do not use this bifurcation, as their departments and agencies are principally not funding entities but delivery organisations. The subnational jurisdictions allocate funding to ministerial portfolios (ministerial budget statements) and within those to agencies for their operational costs, contractual expenses, grants and subsidies and any other expenses they incur. At the Commonwealth level, only the Department of Defence is relatively exempt from the bifurcation between departmental and administered items because of the complicated character of its internal financial management relations. 
(following the consolidation of running costs from the 1980s) has encouraged departments to manage their own budgets conservatively and within budget allocations. Some 95 per cent of Commonwealth agencies have operated each year within budgets for their departmental expenses and regularly underspend on administered items (practising a form of prudential 'in-year' budgetary management).

Australian governments have demonstrated a proficient ability to estimate the budgetary impact of smaller new policies and programs, mostly because these are relatively targeted, time-limited or funding capped. Nevertheless, they have a less than unblemished record in estimating the long-term costs of large policy projects and ones that are unlikely to lapse. Large items of defence spending, for instance, routinely exceed the initial costings in the out-years. In recent times, estimates for the National Disability Insurance Scheme (involving many support programs) were massively underestimated initially, with figures of $\$ 7$ billion blowing out to over $\$ 22$ billion within two years of the initial rollout. Similarly with the National Broadband Network, initial estimates put the price at $\$ 42$ billion, half of which would be provided by the private sector; however, within six years, the figure had increased to $\$ 58$ billion for a downscaled service and no private sector involvement eventuated. Similar blowouts occurred over the decades since the introduction of fees for tertiary education and the income-contingent loans scheme (the Higher Education Contribution Scheme/Higher Education Loan Programme [HECS/HELP]) in 1989 involving the virtual deregulation of student enrolment numbers and a mounting unsecured student loan debt on the federal government's balance sheet, reaching some $\$ 54$ billion in 2017 , with estimates that around one-third would never be repaid.

\section{Assessing value for money in the legislative authorisation stages}

Conventionally, the budget forms the centrepiece of the Budget Session of the Australian Parliament, commencing with a televised evening speech from the Treasurer, outlining the important points in the forthcoming budget. In the days and sometimes weeks before this speech, many of the key details of the budget, including any changes to taxation or spending, have been tactically leaked to the media as a form of expectation management to prepare for its reception. So, even though the budgetary 
papers may run to thousands of pages, parliamentarians and the media are generally well aware of the budget's main items even as it is being tabled. By convention, the opposition leader has the right of reply to the budget two days later, also in a televised speech; in recent years, opposition leaders have opted not to analyse or criticise the main aspects of the government's budget with which they might take issue, but instead to present an entirely alternative budget, hoping to appeal to the public with their policy proposals (effectively turning the 'budget reply speech' into a campaign rally speech).

Parliament then 'debates' the budget. In the House of Representatives, the budget session continues with stage-managed proforma speeches for and against particular budgetary measures, but more in-depth scrutiny is shown by the Senate, where the budget is referred to 'estimate hearings'parliamentary committees with government, opposition and cross-bench senators organised on a sectoral or functional basis. These senate committees generally scrutinise the portfolio budget statements of the portfolio ministers, which contain detailed descriptions of the costs of programs and activities of the departments and agencies, including performance information. Senators and their staff prepare questions, which are asked of senate ministers - sometimes representing their own portfolios, but also being expected to stand in and answer for ministers who sit in the House of Representatives on matters pertaining to their portfolios. In addition, senior officials participate and often answer detailed or technical questions about ongoing programs or the implementation of new policy proposals. The extensively detailed 'portfolio budget statements' provide basic information and the putative 'agenda' for such scrutiny, but questions from senators can range across almost anything within the portfolio. Often this scrutiny consists of teasing out on the public record how the executive will achieve its intended objectives, what targets or performance indicators are pertinent and whether any variations in spending patterns look appropriate. Almost all the scrutiny is directed to the expenditure side of the budget and there is very little attention to the revenue side, although any additional revenue measures may be blocked for political reasons.

In recent years, the Parliamentary Budget Office (PBO) has been established, along the lines of the US Congressional Budget Office, but with a small staff of around 40 officials. The PBO undertakes research and educational activities for parliamentarians (who can ask for assistance or investigations on fiscal and budgetary matters). The office can also initiate 
its own investigations and produce reports for public consumption. A further function of the $\mathrm{PBO}$ is to undertake independent costings of policies that political parties propose close to election times and to assist parties confidentially with preparing costings of their policies (Bowen 2015).

An impartial observer would have to conclude that the Australian legislature does not exercise a rigorous efficiency eye over budgetary estimates and performance expectations at the authorisation stages, and large parts of the budget are passed without any comment or scrutiny. The lower house virtually eschews any serious budgetary scrutiny, although the theatrical spectacle can generate heated polemics. Parliament has relatively little access to alternative sources of data or analytical information with which to contest the government's carefully crafted figures. Non-government parliamentarians tend to engage in rhetorical critiques of spending proposals (that they do not go far enough, they go too far, are likely to lead to waste, low take-up, equity and fairness issues, and so on), but these subjective comments are based on little more than expedient opinions. However, the legislature could exercise a probing analysis of particular programs if members so desired or were prepared to expend the effort, and they could also come back to the issues at subsequent hearings.

\section{Assessing value for money in the post-authorisation stages}

Initially, post-budget monitoring is employed to gauge spending patterns against implementation schedules and milestones, especially for new policy proposals. Such compliance monitoring is not itself a value-formoney exercise, but can ensure implementation plans remain on track for acquittal. The Cabinet Implementation Unit (in PM\&C) performs this limited function for nine to 18 months, but focuses mainly on deliverable activities and project management of specified spending items. Finance can also monitor spending against intended implementation plans and can warn agencies if their expenditures are either excessive or falling behind.

The auditor-general and the ANAO are the main accountability actors engaged in post-budget year evaluations-routinely conducting compliance audits (financial audits) across all agencies and programs (with 
extensive private auditor contractual assistance) and undertaking a small number of performance audits (which often focus on larger material outlays or complicated procurement projects). Presently, the auditorgeneral performs around 50 performance audits in each annual cycle. Audit staff regularly investigate the value-for-money issues under the themes of efficiency and effectiveness, but often report on administrative shortcomings rather than the value of the program to the community or whether any investment was demonstrably worthwhile. So, for example, a regional roads program will be evaluated for being on time, within budget, carefully planned and so on, but not on whether it provides value for money to the community or is worthwhile compared with other projects. In circumstances where the Commonwealth is transferring funds to subnational jurisdictions and earmarking amounts to specific functions, the auditor-general tends to ensure that legal compliance is satisfied with the discharge of the funds; although, in recent years, they have been granted the power by the parliament to conduct 'follow-themoney audits' in conjunction with state auditors (although few of these have actually been attempted to date).

Parliamentary committees using their own powers of investigation supplemented by public hearings can be active in scrutinising 'deliverables' in the post-authorisation stage (asking what was achieved, how effective was it, at what cost, what miscalculations or errors were made). The Joint Committee of Public Accounts and Audit (JCPAA) and sectoral committees (on defence, health, social services, public administration and so on) regularly probe policies or programs considered problematic or sensitive. The JCPAA, in particular, uses ANAO reports to guide its own subsequent investigations about value for money in Commonwealth outlays. However, these committees now rarely undertake in-year audits or site visits to check on progress or delivery, or really delve into the effectiveness of programs in post-year investigations. Instead, politics drives their agendas and they tend to interrogate officials in Parliament House (or other hearing venues) about problems with the program management or even policy parameters.

There are also problems in federal nations with intergovernmental transfers and shared responsibilities for policy sectors. In federal nations, subnational governments will often accept funding proposals initiated by the central government without necessarily being committed to achieving these policy objectives, or will be given money to provide infrastructure or quality social services without being formally obligated to do so. 
Hence, considerable gaming can occur (e.g. over precise commitments, matching funding, the timing of resource commitments-frontending versus back-ending), and some jurisdictions can regard gaming as an expected and legitimate part of intergovernmental relations because subnational jurisdictions enjoy only limited rights to taxation and no guaranteed shares of the taxes raised from their own residents (PM\&C 2015).

In many federal nations, such as Australia, there is limited evaluation of performance where funding crosses jurisdictional boundaries, because, traditionally, neither level had the formal powers or sometimes even the inclination to monitor and hold the other to account. Subnational legislatures rarely (if ever) investigate policies/programs/grants that are specified by the national government but carried out and operationally implemented by state or provincial governments, nor do their principal accountability actors cross jurisdictional boundaries (including their jurisdictional parliamentary committees, auditors-general, commissions of audit, performance bodies or cost commissions). And, if constitutional arrangements prevent substantial institutional redesign, it is hard to make significant political headway over performance in areas of shared responsibilities. While actors can make various occasional pleas for reform—such as separating roles and responsibilities, rebalancing vertical fiscal imbalances, moving to guaranteed revenue shares or transferring responsibilities entirely to one level of government-they have had minimal practical effect. Both federal and state jurisdictions have only just enabled their respective auditors-general to investigate and audit performance over cross-jurisdictional funding arrangements-but this development remains contentious in some subnational governments.

\section{How well does the system cohere?}

In short, Australia's budgetary management system has many strengths and remaining weaknesses. The Australian system for evaluating the efficacy of public finance works partially and episodically, but is far from best practice. Defensive and risk-averse cultures across the public sector still impede transparency and the flourishing of an evaluation ethos that is both forthright and rigorous. Governments have little incentive to 'fess up' if programs are not performing or are failing to achieve their desired objectives; indeed, they are more likely to invest further resources 
in redesigning or rebadging the program than terminating it. The period in the immediate aftermath of a change of government tends to provide the main opportunity to abort or reconfigure underperforming programs (see Laurie and McDonald 2008). One recent initiative, to establish an intergovernmental performance review body to report on comparative state performance within federal funding envelopes, the COAG Reform Council, was quickly abolished in 2013 by the federal government with the blessing of the state premiers. However, since the 1990s, the Productivity Commission has produced the annual Report on Services, which attempts to calculate the comparative costs of delivering services across state and territory jurisdictions. The reports are full of detailed cost assessments and discussion of targeted achievements, but they receive little attention and the reviews have largely focused on the performance in policy sectors administered by state and territory jurisdictions, although, recently, they have been extended to include some Commonwealth programs.

In Australia, accountabilities for performance are still fragmented, piecemeal and sequential rather than combined and holistic. We have installed many windows to shed light into the system and through which to explore value-for-money questions, but they do not all cohere or form an integrated publicly available review. There are occasions when rigorous evaluations have been made in some component part of the system, particularly of new policy proposals, but there is often little longitudinal follow-through analysis that is made public. Moreover, where we have had some integrative aspects of performance review in the past, we have stripped these out in the name of convenience. For instance, the Commonwealth used to require all line agencies to report to the Minister for Finance within six months of receiving an unfavourable audit report what they had done to fix the problems and these departmental/agency reports were published and reviewed by Finance; this was ostensibly a 'closing the loop' provision, but it was abolished in the transition to outcomes-based accrual budgeting in the late 1990s. Agencies found the reporting requirements onerous but trivial in essence, did not take the exercise seriously and reputedly often reported back with defensive comments rather than real responses. 
While some components of the annual budget are closely scrutinised, other areas of significant expenses are not rigorously evaluated unless they attract a dedicated (usually external) review. ${ }^{5}$ Standing appropriations (or 'ongoing' appropriations), which constitute more than 80 per cent of annual outlays, generally receive scant or episodic attention in the budgetary process and continue indefinitely unless they are reviewed in some separate exercise. These standing appropriations include some 20 different forms of pensions and benefits and other entitlements to families and individuals, funding for demand-driven programs such as the Medical Benefits Scheme or the Pharmaceutical Benefits Scheme, grants and ongoing funding to community organisations (administered items), as well as general funding to states and territories, interest payments on debt, and so on. Moreover, many capital budgets (for infrastructure projects, major defence procurements) are not necessarily assessed in terms of value for money, nor judged according to where to make the best investment. Rural, regional and political factors all play a role here, leading to criticism from infrastructure specialists (such as Infrastructure Australia) that funds have been historically misallocated, creating inefficiencies and bottlenecks. Also, Australian politicians are sentimentally attached to their 'ribboncutting mentality' (arranging photo opportunities associated with the opening of events, new facilities or new infrastructure projects), which results in Australian governments spending far more on new infrastructure than their OECD comparators, but much less on basic maintenance and infrastructure upgrades (Infrastructure Australia 2015). There are steps afoot to redress problems with misallocation through bodies such as Infrastructure Australia turning the focus on to 'value capture' in the life cycle of major infrastructure projects.

\section{Other inherent problems limiting higher performance}

In comparative terms, Australia has not developed a strong evaluation culture in public policy. Governments are content to espouse their ostensible objectives when announcing policy initiatives but often do

5 Recently, a number of significant areas of the budget have attracted some form of independent review, often to inquire into their coherence, complexity, integration and funding trends rather than value-for-money questions. These reviews include the Ken Henry Review into taxation, Jeff Harmer's review of pensions and transfers, the Bennett Review of the sustainability of hospital and health funding and various Productivity Commission reviews of housing, gambling, education and training, and so on. 
not collect data on outcomes they have embraced (e.g. environmental sustainability, safer communities and improved community capabilities, improved social cohesion and educational readiness). Many policies are politically driven and governments have invested considerable 'face' in their policies, meaning that unflattering evaluations threaten to embarrass the government or selected ministers. Under such conditions, policies may evade review or be only partially reviewed internally to avoid criticism of the policy intent or design. At the program level, activity reporting rather than measures of effectiveness tends to be collected, which is of limited use in evaluating value-for-money questions.

Across government, data have traditionally been poor and patchy, and much of it was not meaningfully comparable. As the COAG Reform Council argued before it was abolished, making evaluation judgments about the worth of programs on poor-quality data is inherently risky and problematic. Furthermore, the relationship between different sets of indicators pertaining to performance (say, waiting times in hospitals versus health outcomes) is not necessarily straightforward or consistent. Improvements in one measure may come at the cost of another, or a range of indicators measured may have almost nothing to do with one another. Governments find themselves responding to the more visible or more electorally sensitive aspects of policy rather than systemic refinement and recalibration.

In the 1980s and 1990s, many New Public Management adherents argued (and fervently believed) that devolved management with increased discretion and flexibilities in financial management would automatically lead to increased performance; yet, when it came to demonstrating improved performance, they were generally unable to convincingly prove results. The Australian Parliament repeatedly asked the federal government to produce reports evaluating the public sector reforms of the 1980 s and early 1990s, and, although four reports were produced over a decade, they were largely silent on performance improvement-the best was The Australian Public Service Reformed (Task Force on Management Improvement 1992; but see also Wanna et al. 2000; Verspaandonk et al. 2010). And, although the Moran Review into Commonwealth administration (Moran 2010) argued for a comprehensive client-based survey of performance to be routinely undertaken, none ever appeared or has been planned. And, as already mentioned, the Productivity Commission's annual Report on Services provides costing data largely comparing the relative performance of state and territory provisioning, 
but only implicitly analyses the value for money of the various provisions themselves. Agency annual reports have in recent decades reported more information on administrative efficiencies and client service satisfaction relative to publicly announced service charters.

In contrast to some other nations, Australia has been reluctant to use performance incentives to improve performance. There is considerable scepticism in government that performance incentives work well in the public sector and widespread belief that such measures can lead to perverse consequences. For example, rewarding high performers or highperforming units (administrative units, hospitals or schools) can lead to the opposite effects system-wide-through discouragement of low performers, envy, perceptions of fairness and unfairness and fierce disputes over data/ criteria/possibilities. It is not clear whether rewarding high-performing entities actually leads to improved performance in those entities, and fortune/happenstance may have been an important contributor to enhanced performance levels. Some large and some smaller programs have tried to use performance incentives to improve results, but to mixed effect (national partnership payments with performance bonuses, selfresponsibility programs in Indigenous communities, parenting education for troubled families), and governments have usually been forced to pay the increments whatever the diminished levels of performance actually reported. There is also a widespread view that performance pay for officials (or personal bonuses) does not often lead to heightened individual or agency performance, and that, in their application, they can produce resentment, an undue emphasis on individualism, inflated exaggerations of personal contributions, team discouragement and even distorting of data and indicators (ANAO 1993). There are also criticisms of the politicised system of reviewing and awarding individual performance bonuses, which may reward factors not related to actual performance (seniority, reputation, sensitivity, gender, obsequiousness, regional-urban locations, etc.).

A further alternative way to promote performance being actively talked about more recently (and already used in a few policy sectors) is the notion of 'earned autonomy', where high-performing, well-managed entities such as hospitals or selective schools are given greater managerial autonomy to conduct their affairs. Such initiatives are still largely in the experimental stages and used judiciously. It is not yet clear whether 'earned autonomy' initiatives can be applied to poor-performing agencies or programs to improve levels of performance. 


\section{Conclusions}

Australia has developed a sophisticated and comprehensive budget system, with robust processes and budget-setting procedures, including extensive reporting requirements. Over many decades, governments have put in place important managerial reforms to incentivise improved performance, especially since the 1980s. Many budget-related institutions or monitoring bodies are powerful players in the system and wield influence over decision-making. But, despite considerable effort to reorient the budgetary system towards performance management and an emphasis on results, there remain several weaknesses and gaps in the overall system. Arguably, Australia's systems of budgeting and resource allocation have principally been structured to maintain a certain fiscal discipline, but have paid far less attention to establishing and reporting on the value for money taxpayers receive from public policies. The entire budgetary authorisation process has traditionally been structured primarily to satisfy legal requirements rather than to demonstrate criteria of performance, productivity or effectiveness in policies and programs. In budgetary reform, governments at all levels have moved away from line-item budgeting to framing the budget allocations around expected results (e.g. outcomes, outputs, key performance indicators). Budget documentation has been extensively revised to provide results-based frameworks against which resources have been allocated. The impression given is that the government has weighed value-for-money considerations against its expected results and allocated resources accordingly. Yet, cynics might argue that these governments have merely allocated their resources along traditional (legacy) lines and then presented them cosmetically in a result-based packaging. Certainly, more performance information has been included in recent budget documentation (whereas little was included some decades ago), but it is not clear whether an assessment of performance informs the basis for resource allocation. Moreover, criticisms can be levelled that much of the performance information produced by agencies resembles promotional advertising rather than assessments of service quality.

Yet, within these changes, some improvements to administration and operations have occurred because of devolved management and increased discretion afforded to public sector executives. Managers have the capacity to make better management decisions, use alternative and contestable sources of delivery or provision and can better focus on desired results. They are far less constrained by bureaucratic rules and 
regulations governing management, but are still constrained by cascading accountabilities that foster an aversion to risk and openness. As a nation, we are not good at demonstrating the worth of policies or programs or, conversely, of admitting mistakes. There is a manifest hesitancy about being transparent and honest about value for money.

One important holistic reform may be for agencies to explicitly undertake value-for-money investigations of their programs and activities, setting out clearly the criteria on which they base their value-for-money analysis. They could then make the reports of these investigations publicly available, perhaps as a supplement to their annual reports and in budget submissions and bids for new resources. This would help link activitybased performance indicators and subsequent performance reporting with qualitative assessments of the worth of programs and activities. Ideally, these value-for-money reports should be open to independent assessments and critical reflection, perhaps from the ANAO, think tanks, academic centres, accounting firms and management consultants.

So, if outcome budgeting and performance reporting are meant to give legislatures and taxpayers reliable information on the value for money of public provision then there are still major gaps in our governmental systems. Governments have talked about putting a performance lens over budgetary systems for more than 30 years now, and are still talking about the same issue, with new legislation passed in 2013, but without much grounded detail of how improved reporting will occur. They have incorporated results-based corporate and strategic plans in budgetary documentation, but remain reluctant to release detailed information and assessments of performance, especially at program and subprogram levels. Australian legislatures at both state and federal levels have not really exercised their prerogatives to demand meaningful value for money. Until they do, governments will be content to offer activity reporting as a proxy for affirming public value.

\section{References}

Australian National Audit Office (ANAO). 1993. Performance Audit into Performance Bonuses for Executives. Canberra: ANAO.

Australian National Audit Office (ANAO). 1999. Management of Commonwealth budgetary processes. Report No. 38. Canberra: ANAO. 
Blöndal, J. 2008. Budgeting in Australia. Paris: OECD Publishing.

Bowen, P. 2015. The Parliamentary Budget Office: 'Supporting Australian democracy'. Senate Occasional Lecture. Australian Senate, Parliament of Australia, Canberra.

Di Francesco, M. and J. Alford. 2016. Balancing Control and Flexibility in Public Budgeting. Singapore: Palgrave Macmillan. doi.org/10.1007/ 978-981-10-0341-7.

Dowding, K. and A. Martin. 2017. Policy Agendas in Australia. Singapore: Palgrave Macmillan. doi.org/10.1007/978-3-319-40805-7.

Gregory, R. 2017. 'Fiscal outcomes in a time of increasing political spin and unanticipated economic change'. Freebairn Lecture, University of Melbourne, Melbourne, May 2017.

Hawke, L. and J. Wanna. 2010. 'Australia after budget reform: A lapsed pioneer or decorative architect?' In J. Wanna, L. Jensen and J. de Vries (eds) The Reality of Budgetary Reform in OECD Nations: Trajectories and consequences. Cheltenham, UK: Edward Elgar. doi.org/10.4337/9 781849805636.00010 .

Heclo, H. and A. Wildavsky. 1974. The Private Government of Public Money. Berkeley, CA: University of California Press.

Infrastructure Australia. 2015. Australian Infrastructure Audit Report. Canberra: Australian Government.

Kelly, J. and J. Wanna. 2001. 'Are Wildavsky's guardians and spenders still relevant? New public management and the politics of government budgeting'. In L. Jones, J. Guthrie and P. Steane (eds) Learning from International Public Management Reform. Oxford: Elsevier. doi.org/ 10.1016/S0732-1317(01)11016-X.

Kraan, D., I. Hawkesworth, R. Deighton-Smith, J. Kelly and E. Job. 2012. Value for Money in Government: Australia 2012. Paris: OECD Publishing.

Laurie, K. and J. McDonald. 2008. A Perspective on Trends in Australian Government Spending. Canberra: Department of Treasury. 
Moran, T. 2010. Ahead of the Game: Blueprint for the Reform of Australian Government Administration/Advisory Group on Reform of Australian Government Administration. [Moran Review]. Canberra: Department of the Prime Minister and Cabinet.

Prime Minister and Cabinet (PM\&C). 2015. Reform of the Federation. Issues Paper No. 5. Canberra: Council of Australian Governments and Federal Financial Relations, Department of the Prime Minister and Cabinet.

Posner, P. and J. Blöndal. 2012. 'Deficits and democracy: Prospects for fiscal responsibility in democratic nations'. Governance: An International Journal of Policy, Administration and Institutions 25(1): 11-34. doi.org/10.1111/j.1468-0491.2011.01554.x.

Task Force on Management Improvement. 1992. The Australian Public Service Reformed: An evaluation of a decade of management reform. Canberra: AGPS.

Verspaandonk, R., I. Holland and N. Horne. 2010. A chronology of changes in the Australian Public Service 1975-2010. Parliamentary Library Background Paper. Canberra: Parliament of Australia.

Wanna, J., J. Forster and J. Kelly. 2000. Managing Public Expenditure in Australia. Sydney: Allen \& Unwin.

Wanna J., L. Jensen and J. de Vries (eds). 2010. The Reality of Budgetary Reform in OECD Nations: Trajectories and consequences. Cheltenham, UK: Edward Elgar.

Young, L. 1996. Minor Players? The Senate, the minor parties and the 1993 budget. Parliamentary Fellow Monographs. Canberra: Parliament of Australia. 


\section{Appendix 2.1 Commonwealth budget timelines}

The following timeline is followed in the lead-up to the presentation of the budget to Parliament.

\begin{tabular}{|c|c|c|}
\hline $\begin{array}{l}\text { Timeline } \\
\text { (calendar month) }\end{array}$ & $\begin{array}{l}\text { Event or review } \\
\text { process }\end{array}$ & What occurs \\
\hline $\begin{array}{l}\text { September } \\
\text { to November }\end{array}$ & $\begin{array}{l}\text { Pre-budget } \\
\text { submissions }\end{array}$ & $\begin{array}{l}\text { The treasurer issues a press release calling } \\
\text { for pre-budget submissions from interested } \\
\text { parties. This allows for consultation with the } \\
\text { community on priorities for the next budget. }\end{array}$ \\
\hline $\begin{array}{l}\text { November } \\
\text { or December }\end{array}$ & $\begin{array}{l}\text { Senior } \\
\text { ministers' } \\
\text { review }\end{array}$ & $\begin{array}{l}\text { Portfolio ministers' new proposals and } \\
\text { expected major pressures on agency budgets } \\
\text { are considered, and priorities for the coming } \\
\text { budget are established. The ministers who } \\
\text { attend this review are the prime minister, } \\
\text { the deputy prime minister, the treasurer and } \\
\text { the minister for finance and administration. }\end{array}$ \\
\hline February & $\begin{array}{l}\text { Portfolio budget } \\
\text { submissions }\end{array}$ & $\begin{array}{l}\text { To seek funding for new policy proposals, } \\
\text { agencies prepare portfolio budget submissions } \\
\text { based on the outcome of the senior ministers' } \\
\text { review. The submissions outline all major } \\
\text { proposals that agencies wish to have funded } \\
\text { and potential savings. }\end{array}$ \\
\hline March & $\begin{array}{l}\text { Expenditure } \\
\text { Review } \\
\text { Committee }\end{array}$ & $\begin{array}{l}\text { This subcommittee of Cabinet is primarily } \\
\text { responsible for developing the budget against } \\
\text { the background of the government's political, } \\
\text { social and economic priorities. It decides which } \\
\text { of the agencies' proposals will be funded and } \\
\text { by how much. Membership varies, but usually } \\
\text { comprises the prime minister, the treasurer, } \\
\text { the minister for finance and administration } \\
\text { and one or two other ministers. }\end{array}$ \\
\hline March or April & $\begin{array}{l}\text { Ad Hoc } \\
\text { Revenue } \\
\text { Committee }\end{array}$ & $\begin{array}{l}\text { The Ad Hoc Revenue Committee is also } \\
\text { a Cabinet committee. It meets after the ERC to } \\
\text { decide the revenue components of the budget. }\end{array}$ \\
\hline April & Budget Cabinet & $\begin{array}{l}\text { This is the final stage in the decision-making } \\
\text { process. Decisions from the ERC are endorsed } \\
\text { and the budget Cabinet agrees to present the } \\
\text { budget to parliament. }\end{array}$ \\
\hline May & $\begin{array}{l}\text { Presentation } \\
\text { to parliament } \\
\text { ('Budget Night') }\end{array}$ & $\begin{array}{l}\text { The budget is usually brought down on the } \\
\text { second Tuesday in May. The government } \\
\text { presents the budget papers and budget- } \\
\text { related documents. The treasurer summarises } \\
\text { the budget in the Budget Speech, which is } \\
\text { traditionally presented at } 7.30 \text { pm on budget } \\
\text { night and televised. }\end{array}$ \\
\hline
\end{tabular}




\begin{tabular}{|c|c|c|}
\hline $\begin{array}{l}\text { Timeline } \\
\text { (calendar month) }\end{array}$ & $\begin{array}{l}\text { Event or review } \\
\text { process }\end{array}$ & What occurs \\
\hline September & $\begin{array}{l}\text { Final Budget } \\
\text { Outcome report }\end{array}$ & $\begin{array}{l}\text { The Charter of Budget Honesty Act } 1998 \\
\text { requires that a Final Budget Outcome be } \\
\text { released no later than three months after the } \\
\text { end of the relevant financial year. The financial } \\
\text { statements in the Final Budget Outcome are } \\
\text { similar to those in the budget but provide actual } \\
\text { outcomes rather than estimates. }\end{array}$ \\
\hline December & $\begin{array}{l}\text { Mid-Year } \\
\text { Economic and } \\
\text { Fiscal Outlook }\end{array}$ & $\begin{array}{l}\text { The mid-year half-yearly update must be } \\
\text { released by the end of January or six months } \\
\text { after the budget is handed down, whichever } \\
\text { is later. It provides a full update of changing } \\
\text { assumptions, expenses and any policy } \\
\text { changes affecting the budget. }\end{array}$ \\
\hline Three-yearly & $\begin{array}{l}\text { Pre-Election } \\
\text { Fiscal Outlook } \\
\text { (PEFO) }\end{array}$ & $\begin{array}{l}\text { The Charter of Budget Honesty Act } 1998 \\
\text { requires that a PEFO be released in election } \\
\text { years. The purpose of the PEFO is to update } \\
\text { information on the economic and fiscal } \\
\text { outlook before an election. A PEFO must be } \\
\text { released publicly within } 10 \text { days of the issue } \\
\text { of the writ for a general election, and must } \\
\text { contain spending and revenue estimates for } \\
\text { the current and following three financial years, } \\
\text { the assumptions underlying the estimates, } \\
\text { the sensitivity of the estimates to changes } \\
\text { in assumptions and risks that might materially } \\
\text { change the fiscal outlook. }\end{array}$ \\
\hline
\end{tabular}


This text is taken from Value for Money: Budget and financial management reform in the People's Republic of China, Taiwan and Australia, edited by Andrew Podger, Tsai-tsu Su, John Wanna, Hon S. Chan and Meili Niu, published 2018 by ANU Press, The Australian National University, Canberra, Australia. 